Volume 6 No. 1 April 2019

P-ISSN 2355-2700 E-ISSN 2550-0139

http://ejournal.bsi.ac.id/ejurnal/index.php/moneter

\title{
Pengaruh Restitusi Kelebihan Pembayaran Pajak Pertambahan Nilai Pada Kantor Pelayanan Pajak Pratama Jakarta Penjaringan
}

\author{
Dinar Riftiasari \\ Universitas Bina Sarana Informatika \\ Fakultas Ekonomi Dan Bisnis \\ Email: dinar.drf@bsi.ac.id
}

(Riftia, 2019) Riftia, D. (2019). Pengaruh Restitusi Kelebihan Pembayaran Pajak Pertambahan Nilai Pada Kantor Pelayanan Pajak Pratama Jakarta Penjaringan. Moneter, 6(1), 63-68.

\begin{abstract}
Tax is the main source of state revenue used to finance state expenditures, tax classification based on collection, tax consists of central tax and local tax. Central tax is a tax managed by the central government to finance expenses state budget and local tax is a tax managed by the regional government to finance expenses local government budget. The Value Added Tax is central tax, tax payment amount payable by the amount of the tax credit shows the amount of excess have been made that should tax refunds. The purpose of this study was to determine the effect of value added tax restitution of value added tax revenue and procedure for implementing value added tax restitution in the Tax Office Pratama Jakarta Penjaringan. Method used in the study is a quantitative method. This research is value added tax restituition that occurred output tax is greater than input tax in the Tax Office Pratama Jakarta Penjaringan the implementation of restitution does not has any effect toward value added tax revenue. The Standar Operating Procedures of value added tax restitution in the Tax Office Pratama Jakarta Penjaringan is Standar Operating Procedures No KPP50-0004.
\end{abstract}

Keywords: Value Added Tax, Restitution, Tax Revenues

\section{PENDAHULUAN}

Pajak merupakan sumber utama penerimaan negara yang digunakan untuk membiayai pengeluaran negara, penggolongan pajak berdasarkan lembaga pemungutannya pajak terdiri atas pajak pusat dan pajak daerah. Pajak pusat atau pajak negara merupakan pajak yang dikelola oleh pemerintah pusat seperti Pajak Penghasilan (PPh), Pajak Pertambahan Nilai (PPN), dan Bea Materai dimana penerimaan Pajak pusat hasilnya dipergunakan untuk membiayai pengeluaran rutin negara dan pembangunan Anggaran Pendapatan Belanja Negara (APBN) dan pajak daerah adalah pajak yang dikelola oleh pemerintah daerah baik tingkat provinsi maupun kabupaten atau kota yang mana dipergunakan untuk membiayai pengeluran sebagai sumber penerimaan Anggaran Pendapatan Belanja Daerah (APBD).

Sumber penerimaan pajak pusat salah satunya berasal dari Pajak Pertambahan Nilai (PPN) yang dikenakan terhadap Pengusaha Kena Pajak (PKP) yang melakukan penyerahan atas barang kena pajak (BKP) maupun penyerahan Jasa Kena Pajak (JKP) yang diatur dalam Undang-undang PPN Nomor 42 Tahun 2009, PKP memiliki kewajiban menyetorkan PPN yang telah dipungut ke kas negara, dalam hal penyetoran atau pembayaran PPN ternyata pajak keluaran lebih besar daripada pajak masukan maka PPN mengalami kurang bayar sebaliknya jika pajak masukan lebih besar daripada pajak keluaran maka kelebihan bayar PPN dapat dikompensasikan atau direstitusi.

PKP yang memiliki jumlah kredit pajak lebih besar dari pajak terutang berhak mengajuan pengembalian kelebihan pembayaran PPN atau restitusi. Restitusi dapat dilakukan jika PKP tidak memiliki hutang pajak lainnya, selain itu ada prosedur lainnya yang harus dipenuhi apabila PKP ingin mengajukan restitusi kepada Kantor Pelayanan Pajak Pratama (KPP) Jakarta Penjaringan. Berdasarkan latar belakang masalah diatas maka permasalahan dalam penelitian ini adalah Apakah terdapat pengaruh Restitusi PPN terhadap Penerimaan PPN pada KPP Jakarta Penjaringan? dan Bagaimana Prosedur pelaksanaan Restitusi PPN pada KPP Jakarta Penjaringan?

\section{Pengertian Pajak Pertambahan Nilai}

Pajak Pertambahan Nilai adalah pajak yang dikenakan atas konsumsi, baik konsumsi Barang Kena Pajak maupun Jasa Kena Pajak di dalam Daerah Pabean oleh orang pribadi ataupun badan, yang dikenakan secara bertingkat pada setiap produksi dan distribusi barang atau jasa. (UndangUndang Nomor 42 Tahun 2009)

\section{Karakteristik Pajak Pertambahan Nilai}

Karakteristik Pajak Pertambahan Nilai Indonesia dalam (Sukardji, 2014) dapat dirinci sebagai berikut: 
a. Pajak Pertambahan Nilai merupakan pajak tidak langsung

b. Pajak objektif

c. Multi stage tax

d. PPN terutang untuk dibayar ke kas negara dihitung menggunakan indirect subraction method/credit method/invoice method

e. Pajak Pertambahan Nilai adalah pajak atas konsumsi umum dalam negeri

f. Pajak Pertambahan Nilai bersifat netral

g. Tidak menimbulkan dampak pengenaan pajak berganda

\section{Subjek Pajak Pertambahan Nilai}

Menurut (Priantara, 2015) subjek PPN yang bertanggung jawab terhadap pemungutan, penyetoran dan pelaporan PPN

a. Pengusaha

Adalah orang pribadi atau badan dalam bentuk apapun yang dalam kegiatan usaha atau pekerjaannya menghasilkan barang, mengimpor barang, mengekspor barang atau jasa, melakukan usaha perdagangan, memanfaatkan barang tidak berwujud dari luar daerah pabean, melakukan usaha jasa, atau memanfaatkan jasa dari luar daerah pabean

b. PKP

Adalah pengusaha yang melakukan penyerahan BKP dan atau penyerahan JKP yang dikenakan pajak berdasarkan UU PPN, tidak termasuk pengusaha kecil yang batasannya ditetapkan dengan keputusan Menteri Keuangan

c. Bukan PKP

Dijelaskan dalam UU PPN bahwa PKP adalah pengusaha yang melakukan penyerahan BKP dan JKP yang dikenakan pajak berdasarkan UU PPN. Ini berarti tidak semua pengusaha adalah PKP. Contohnya pengusaha restoran, hotel, perusahaan daerah air minum, rumah sakit, dokter praktek. Pada contoh tersebut barang atau jasa yang diserahkan bukan BKP atau JKP. Pengusaha yang tidak menghasilkan BKP dan/atau JKP meskipun tidak termasuk pengusaha kecil adalah bukan PKP. Dengan demikian, yang termasuk bukan PKP adalah Pengusaha kecil, kecuali pengusaha kecil yang bersangkutan sukarela memilih untuk dikukuhkan sebagai PKP dan Pengusaha yang menghasilkan dan/atau menyerahkan bukan BKP dan/atau bukan JKP

\section{Objek Pajak Pertambahan Nilai}

Menurut (Waluyo, 2010) Pajak Pertambahan Nilai dikenakan atas:

a. Penyerahan Barang Kena Pajak di dalam Daerah Pabean yang dilakukan oleh Pengusaha

b. Impor Barang Kena Pajak

c. Penyerahan Jasa Kena Pajak yang dilakukan di dalam Daerah Pabean yang dilakukan oleh Pengusaha d. Pemanfaatan Barang Kena Pajak tidak berwujud dari luar Daerah Pabean di dalam Daerah Pabean

e. Pemanfaatan Jasa Kena Pajak dari luar Daerah Pabean di dalam Daerah Pabean

f. Ekspor Barang Kena Pajak Berwujud oleh Pengusaha kena Pajak

g. Ekspor Barang Kena Pajak Tidak Berwujud oleh Pengusaha kena Pajak

h. Ekspor Jasa Kena Pajak oleh Pengusaha kena Pajak

\section{Dasar Pengenaan Pajak Pertambahan Nilai}

Dalam (Mardiasmo, 2018) Dasar Pengenaan Pajak (DPP) adalah:

a. Harga jual adalah nilai berupa uang, termasuk semua biaya yang diminta atau seharusnya diminta oleh penjualkarena penyerahan BKP, tidak termasukPajak Pertambahan Nilaiyang dipungut menurut UU PPN 1984 dan potongan harga yang dicantumkan dalam faktur pajak.

b. Penggantian adalah nilai berupa uang, termasuk semua biaya yang diminta atau seharusnya diminta oleh pengusaha karena penyerahan JKP, ekspor JKP, atau ekspor BKP tidak berwujud, tetapi tidak termasuk Pajak Pertambahan NIlai yang dipungut menurut Undang-Undang PPN 1984 dan potongan harga yang dicantumkan dalam faktur pajak atau nilai berupa uang yang dibayar atau seharusnya dibayar oleh penerima jasa karena pemanfaatan BKP tidak berwujud dari luar Daerah Pabean di dalam Daerah Pabean.

c. Nilai impor adalah nilai berupa uang yang menjadi dasar penghitunganbea masuk di tambah pungutan berdasarkan ketentuan dalam peraturan perundangundangan yang mengatur mengenai kepabeanan dan cukai untuk impor BKP, tidak termsuk PPN dan PPnBM yang dipungut menurut Undang-Undang PPN 1984.

d. Nilai ekspor adalah niali berupa uang, termasuk biaya yang diminta atau seharusnya diminta oleh pengekspor

e. Nilai lain yang diatur dengan Peraturan menteri Keuangan

\section{Tarif Pajak Pertambahan Nilai}

Tarif PPN berdasarkan (Undang-Undang Nomor 42 Tahun 2009)

a. Tarif PPN adalah $10 \%$

b. Tarif PPN sebesar 0\% diterapkan atas Ekspor Barang Kena Pajak Berwujud, Ekspor Barang Kena Pajak Tidak Berwujud, Ekspor Jasa Kena Pajak

c. Tarif pajak sebagaimana dimaksud pada ayat (1) dapat berubah menjadi paling rendah $5 \%$ dan paling tinggi sebesar $15 \%$ sebagaimana diatur oleh Peraturan Pemerintah

d. Pengenaan tarif 0\% tidak berarti pembebasan dari pengenaan Pajak Pertambahan Nilai. Dengan demikian, Pajak Masukan yang telah dibayar 
untuk perolehan $\mathrm{BKP} / \mathrm{JKP}$ yang berkaitan dengan kegiatan tersebut dapat dikreditkan (Mardiasmo, 2018)

\section{Batas Waktu Penyetoran Dan Pelaporan SPT Masa PPN}

Batas waktu penyetoran PPN dan pelaporan SPT Masa PPN sesuai PER Dirjen Pajak No.14/PJ/2010 dalam (Pohan, 2016) sebagai berikut:

a. PPN dan PPnBM yang terutang dalam satu masa pajak, harus disetor paling lama akhir bulan berikutnya setelah berakhirnya masa pajak dan sebelum SPT Masa PPN disampaikan. Dalam hal tanggal jatuh tempo penyetoran bertepatan dengan hari libur termasuk hari Sabtu atau hari libur Nasional, penyetoran dapat dilakukan pada hari kerja berikutnya

b. SPT Masa PPN harus disampaikan paling lambat akhir bulan berikutnya setelah berakhirnya Masa Pajak. Dalam hal akhir bulan adalah hari libur termasuk hari Sabtu atau hari libur Nasional, maka SPT Masa PPN dapat disampaikan pada hari kerja berikutnya

Keterlambatan pelaporan SPT masa PPN dikenai denda Rp 500.000, sedangkan keterlambatan penyetoran PPN dikenai denda bunga $2 \%$ per bulan dari PPN yang terutang.

\section{Restitusi Pajak Pertambahan Nilai}

Dalam (Sukardji, 2014) Apabila jumlah Pajak Masukan yang dibayar lebih besar daripada jumlah Pajak Keluaran yang dipungut, maka kelebihan pembayaran Pajak Masukan tersebut harus dikembalikan untuk dimasukkan kembali ke kas perusahaan. Kelebihan pembayaran Pajak Masukan pada suatu masa pajak, dapat disebabkan oleh:

a. Jumlah Pajak Masukan lebih besar daripada jumlah Pajak Keluaran

b. PKP melakukan kegiatan ekspor BKP yang tergolong mewah

c. Kesalahan Pemungutan

Berdasarkan (Wisanggeni, 2018) pengembalian kelebihan pembayaran pajak (restitusi) terjadi apabila jumlah kredit pajak atau jumlah pajak yang dibayar lebih besar daripada jumlah pajak yang terutang atau telah dilakukan pembayaran pajak yang tidak seharusnya terutang, dengan catatan WP tidak punya hutang pajak lain. Tata cara pengembalian kelebihan pembayaran pajak:

a. Wajib Pajak (WP) dapat mengajukan permohonan restitusi ke Direktur Jenderal Pajak (DJP) melalui KPP setempat

b. DJP setelah melakukan pemeriksaan, menerbitkan Surat Ketetapan Pajak Lebih Bayar (SKPLB)

c. SKPLB diterbitkan oleh DJP paling lambat 12 bulan sejak surat permohonan diterima secara lengkap, kecuali untuk kegiatan tertentu ditetapkan lain dengan keputusan DJP

d. Apabila dalam jangka waktu 12 bulan sejak permohonan restitusi, DJP tidak memberikan keputusan, maka permohonan dianggap dikabulkan, dan SKPLB diterbitkan dalam jangka waktu paling lambat 1 bulan setelah jangka waktu berakhir.

Dalam sistem PPN, terdapat tiga metode yang dapat digunakan untuk mengembalikan kelebihan pembayaran pajak masukan menurut Alan Schenk dan Oliver Oldman dalam (Darussalam, Septriadi, \& Dhora, 2018) sebagaimana dapat dilihat pada gambar 1 berikut

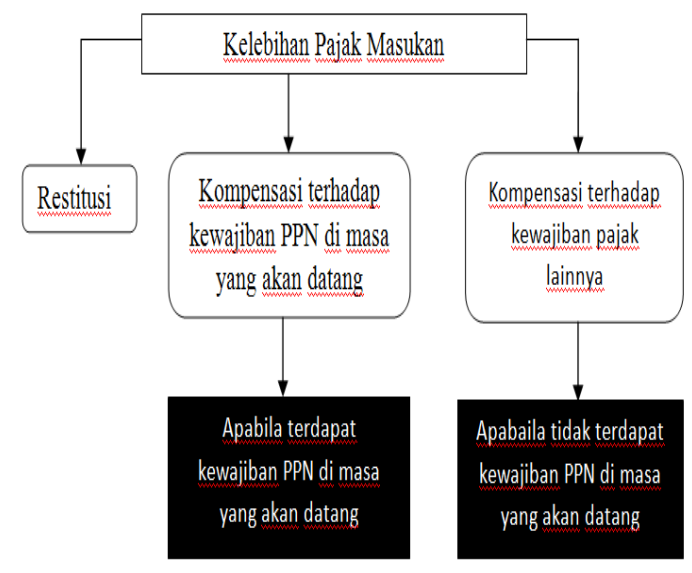

Gambar 1 Metode Pengembalian Kelebihan Pajak Masukan dalam Sistem PPN

Menurut (Pohan, 2016) Wajib pajak tertentu yang memiliki risiko rendah dapat diberikan restitusi dengan pengembalian pendahuluan tanpa melalui pemeriksaan terlebih dahulu. Pemeriksaan dapat dilakukan kemudian bila diperlukan. Sanksi yang dikenakan lebih rendah dari Undang-Undang KUP yaitu $2 \%$ per bulan, kecuali terdapat indikasi tindak pidana perpajakan, maka sanksi yang berlaku sesuai ketentuan sebagaimana diatur dalam UU KUP. Kriteria umum bagi manajemen dalam memutuskan perlu tidaknya mengajukan permohonan restitusi PPN adalah:

a. Bila besarnya PPN yang lebih bayar tersebut cukup signifikan/material jumlahnya

b. Bila kondisi keuangan perusahaan mengalami gangguan cash flow

c. Bila sudah diyakini kesiapan perusahaan untuk diperiksa oleh fiskus

d. Bila prediksi masa depan pembayaran PPN menunjukkan lebih bayar PPN

Mekanisme restitusi dibagi menjadi dua, yaitu mekanisme umum dan mekanisme khusus. Mekanisme khusus merupakan mekanisme restitusi yang berlaku bagi PKP berisiko rendah, wajib pajak dengan kriteria tertentu, dan wajib pajak yang memenuhi persyaratan tertentu menurut (Darussalam, Septriadi, \& Dhora, 2018) 


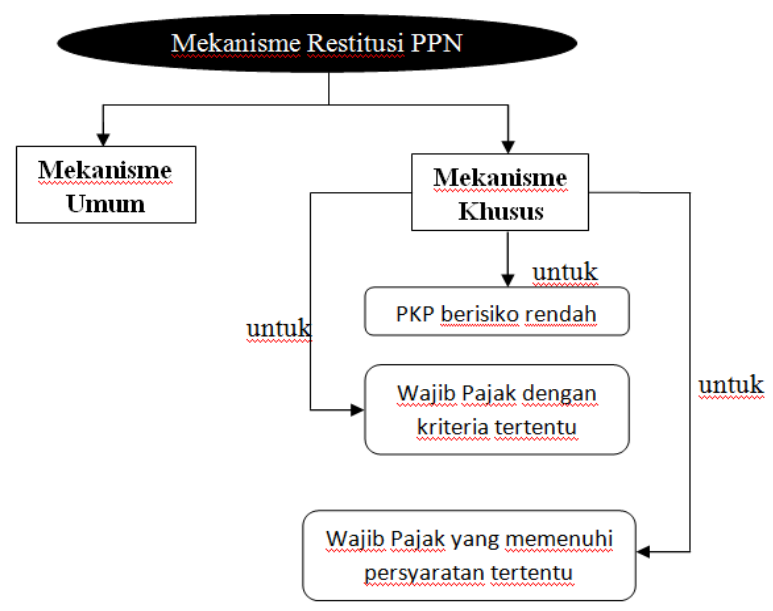

Gambar 2 Mekanisme Restitusi PPN

\section{METODOLOGI PENELITIAN}

Metode yang digunakan dalam penelitian ini adalah metode deskriptif kuantitatif mengenai pengaruh restitusi PPN terhadap penerimaan PPN. Pengumpulan data dalam penelitian ini menggunakan data sekunder mengenai rekapitulasi Restitusi PPN dan Penerimaan PPN tahun 2013-2017 yang diperoleh peneliti dari Kantor Pelayanan Pajak Pratama Jakarta Penjaringan. Dalam penelitian ini yang menjadi populasi adalah Restitusi dan penerimaan PPN pada Kantor Pelayanan Pajak Pratama Jakarta Penjaringan. Sampel penelitian ini adalah hasil Penerimaan Restitusi dan PPN pada tahun 2013-2017.

Variabel dalam penelitian ini terdiri dari variabel independen (X) Restitusi PPN dan variabel dependen (Y) Penerimaan PPN. Kerangka pemikiran penelitian ini adalah:

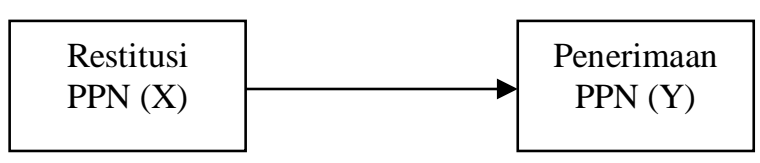

Gambar 3 Kerangka Pemikiran Penelitian

Penelitian ini menggunakan teknik analisis regresi sederhana, cara mengetahui pengaruh antara variabel bebas yaitu Restitusi PPN dan variabel terikat yaitu Penerimaan PPN. Menurut Priyatno dalam (Jusmani \& Qurniawan, 2016) Analisis Regresi Linier Sederhana adalah untuk mengetahui pengaruh atau hubungan secara linier antara satu variabel independen dengan satu variabel dependen. dengan bentuk persamaan:

$\mathrm{Y}=\mathrm{a}+\mathrm{bX}$

$\mathrm{Y}=$ variabel dependent $(\mathrm{PPN})$

$\mathrm{X}=$ variabel independent (Restitusi PPN)

$\mathrm{A}=$ nilai konstanta

$\mathrm{B}=$ koefisien regresi

\section{HASIL DAN PEMBAHASAN}

\section{Data Restitusi PPN Dan Penerimaan PPN}

Nilai restitusi PPN pada Kantor Pelayanan Pajak Pratama Jakarta Penjaringan tahun pajak 2013-2017 dapat dilihat pada tabel 1 dibawah ini:

Tabel l

Data Penerimaaan dan Restitusi PPN

\begin{tabular}{|c|cc|c|}
\hline Tahun & \multicolumn{2}{|c|}{ Restitusi PPN } & Penerimaan PPN \\
\hline 2013 & $\mathrm{Rp}$ & 2.865 .129 .701 & $\mathrm{Rp} 351.272 .894 .175$ \\
\hline 2014 & $\mathrm{Rp}$ & 14.813 .747 .707 & $\mathrm{Rp} 391.441 .516 .832$ \\
\hline 2015 & $\mathrm{Rp}$ & 64.861 .123 .977 & $\mathrm{Rp} 637.971 .141 .868$ \\
\hline 2016 & $\mathrm{Rp}$ & 74.030 .412 .977 & $\mathrm{Rp} \mathrm{522.256.167.324}$ \\
\hline 2017 & $\mathrm{Rp}$ & 56.715 .110 .738 & $\mathrm{Rp} 839.782 .549 .428$ \\
\hline
\end{tabular}

Sumber : Seksi PDI KPP Pratama Jakarta Penjaringan

\section{Pengaruh Restitusi PPN Terhadap Penerimaan PPN}

Dalam penelitian ini data Restitusi PPN dan Penerimaan PPN di uji menggunakan bantuan program SPSS Statistics 21 yang diolah dengan menggunakan uji analisis regresi linier sederhana. Adapun hasil yang diperoleh sebagai berikut:

Tabel 2

\begin{tabular}{|l|r|r|r|c|}
\hline \multicolumn{5}{|c|}{ Model Summary } \\
\hline Model & \multicolumn{1}{|c|}{$\mathrm{R}$} & R Square & $\begin{array}{c}\text { Adjusted R } \\
\text { Square }\end{array}$ & $\begin{array}{c}\text { Std. Error of the } \\
\text { Estimate }\end{array}$ \\
\hline 1 &, $694^{\mathrm{a}}$ &, 482 &, 309 & 6,00581 \\
\hline
\end{tabular}

a. Predictors: (Constant), Restitusi PPN

b. Dependent Variable: Penerimaan PPN Sumber : Data diolah (2019)

Berdasarkan tabel 2 menunjukkan nilai korelasi $\mathrm{R}$ adalah 0,694 atau 69,4\% dapat diinterprestasikan bahwa Restitusi PPN (X) memiliki hubungan yang kuat dengan Penerimaan PPN (Y) di KPP Pratama Jakarta Penjaringan karena berada diatas 0,50. Nilai $\mathrm{R}$ Square atau R2 sama dengan 0,482 atau 48,2\% artinya bahwa variabel bebas yaitu Restitusi PPN (X) memiliki pengaruh kontribusi sebesar 48,2\% terhadap variabel terikat yaitu Penerimaan PPN (Y) dan 51,8\% lainnya dipengaruhi oleh Faktor-faktor lain diluar variabel Restitusi PPN (X). 


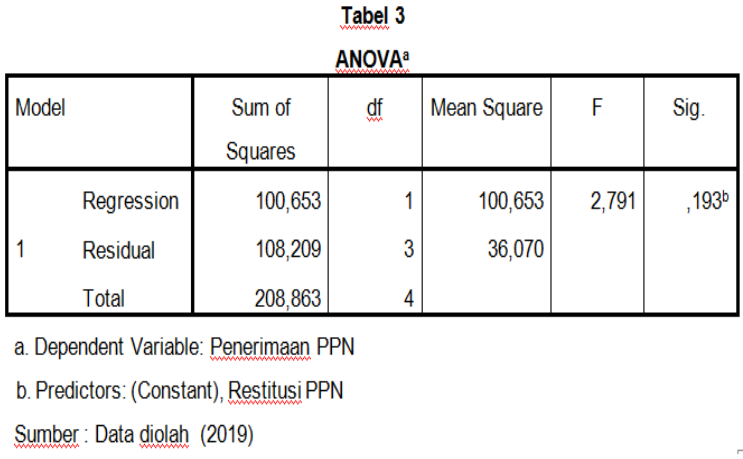

Berdasarkan tabel 3, diperoleh nilai Signifikansi sebesar 0,193 yang berarti lebih besar dari 0,05 dengan demikian model persamaan regresi berdasarkan data penelitian adalah tidak signifikan dimana model regresi linier tidak mempengaruhi variabel dependent. Dengan demikian Restitusi PPN tidak berpengaruh terhadap Penerimaan PPN di KPP Pratama Jakarta Penjaringan.

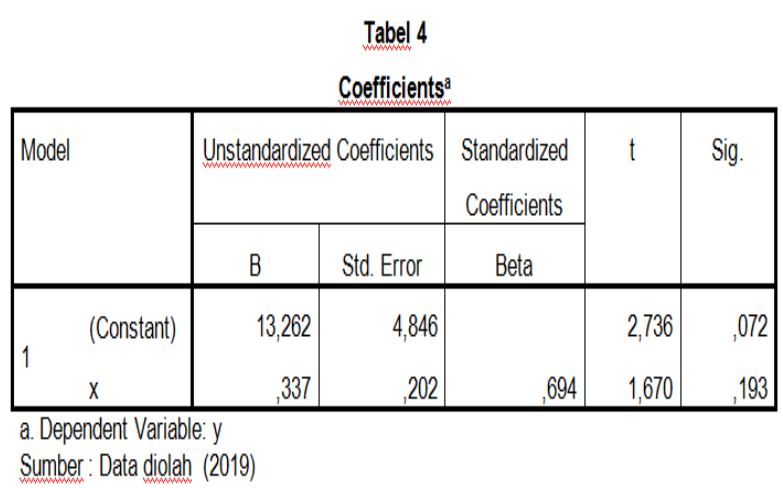

Berdasarkan tabel 4 maka dapat diperoleh persamaan regresi linear antara variabel independent dan variabel dependent adalah $\mathrm{Y}=13,262+0,337 \mathrm{X}$ dapat diketahui bahwa hubungan antara hasil Restitusi PPN bernilai positif. Artinya, setiap peningkatan hasil Restitusi PPN akan meningkatkan Penerimaan PPN sebesar 0,337\%. Dari hasil output didapat signifikasi untuk restitusi PPN yaitu sebesar $0,193>0,05$ yang berarti Restitusi PPN tidak berpengaruh signifikan terhadap Penerimaaan PPN pada KPP Pratama Jakarta Penjaringan.

\section{Prosedur Pelaksanaan Restitusi PPN}

Prosedur dalam pelaksanaan Restitusi PPN di KPP Pratama Jakarta Penjaringan berdasarkan pedoman SOP (Standar Operating Procedures) Nomor KPP50-0004 tentang Tata Cara Penyelesaian Permohonan Pengembalian Kelebihan PPN untuk selain Wajib Pajak yang memenuhi kriteria tertentu dan Wajib Pajak yang memenuhi persyaratan tertentu di KPP Pratama Jakarta Penjaringan terdapat 4 tahapan yaitu:

a. Tahap Permohonan

1) Pemohon yang memiliki Kelebihan Pembayaran PPN dapat mengajukan 2 hal, yaitu kompensasi dan juga Pengembalian
Kelebihan Pembayaran Pajak (Restitusi). PKP yang memiliki Kelebihan Pembayaran dapat menentukan sendiri untuk melakukan kompensasi atau restitusi.

2) Kompensasi dipilih untuk menutupi ulang pajak tahun-tahun berikutnya seandainya terjadi kekurangan pembayaran pajak, sedangkan untuk restitusi salah satu alasan PKP melakukannya adalah karena situasi dari perusahaan tersebut yang kemungkinan membutuhkan dana.

3) Penulis berfokus pada Pengembalian Kelebihan Pembayaran Pajak (Restitusi).

4) Wajib Pajak mengajukan permohonan Pengembalian Kelebihan Pembayaran PPN beserta lampirannya atau Surat Permohonan Pengembalian Kelebihan Pembayaran Pajak.

5) Kelengkapan dari permohonan restitusi dapat diserah setelah diserahkannya permohonan dan paling lambat 1 bulan sejak permohonan diterima.

6) Jika pemohon tidak melengkapi atau kurang melengkapi kelengkapan permohonan, maka pemeriksaan akan dilakukan berdasarkan dokumen yang telah diterima.

7) Jika kelengkapan permohonan disampaikan dalam jangka waktu lebih satu bulan sejak diterimanya permohonan, maka bukti-bukti atau dokumen-dokumen tersebut tidak diperhitungkan dalam pemeriksaan, keberatan, dan banding.

b. Tahap Pemeriksaan

1) Setelah SPT Masa diterima dan direkam, SPT Masa lebih bayar selanjutnya diserahkan ke seksi pemeriksaan untuk diproses dengan SOP Tata Cara Pemeriksaan.

2) Seksi Pemeriksaan selanjutnya menyerahkan Nota Penghitungan dan LPH sebagai produk dari SOP Tata Cara Pemeriksaan kepada seksi pelayanan.

3) Seksi pemeriksaan hanya diberikan waktu 4 bulan untuk mengurus hal tersebut, dan dapat diperpanjang menjadi 8 bulan jika hal tersebut tidak dikeluarkan keputusan tersebut maka permohonan WP dianggap diterima.

c. Tahap Penetapan

1) Seksi pelayanan kemudian memproses nota penghitungan dan LHP sesuai dengan Penerbitan Surat Ketetapan Pajak.

2) Penerbitan Surat Ketetapan Pajak bisa berupa SKPKB, SKPLB, dan SKPN sesuai dengan Nota Penghitungan dan LHP. Dalam hal produk hukum berupa SKPLB, selanjutnya diproses dengan Tata Cara Penerbitan Surat Perintah Membayar 
Kelebihan Pajak (SPMKP) di Seksi Pengawasan dan Konsultasi.

3) Jangka waktu SPMKP yaitu 1 bulan setelah diterbitkan SKPLB. SKPKB, SKPLB, dan SKPN yang sudah dicetak kemudian diproses sesuai dengan Tata Cara Penatausahaan Dokumen Wajib Pajak dan Tata Cara Penyampaian Dokumen di KPP.

4) Proses selesai. Keseluruh proses di atas harus selesai dalam waktu 12 bulan sejak saat diterimanya permohonan secara lengkap sesuai dengan yang telah ditentukan.

d. Tahap Pencairan

a) SPMKP (Surat Perintah Membayar Kelebihan Pembayaran Pajak dikirimkan kepada kantor KPPN (Kantor Pelayanan Pembendaharaan Negara) untuk kemudian dicairkan.

b) KPPN mengirimkan Kelebihan Pajak kepada Wajib Pajak atau Pengusaha Kena Pajak dan dana dikirimkan ke rekening Wajib Pajak.

\section{KESIMPULAN}

Berdasarkan hasil penelitian pengaruh Restitusi PPN terhadap Penerimaaan PPN pada KPP Pratama Jakarta Penjaringan, maka dapat ditarik beberapa kesimpulan sebagai berikut:

1. Restitusi PPN tidak mempengaruhi Penerimaan PPN pada KPP Pratama Jakarta Penjaringan dengan Nilai signifikansi sebesar 0,193 dan nilai korelasi adalah 0,694 dimana kedua variabel memiliki hubungan yang kuat karena berada diatas 0,50 dengan Nilai R Square 48,2\% artinya bahwa Restitusi PPN memiliki pengaruh kontribusi sebesar 48,2\% terhadap Penerimaan PPN dan $51,8 \%$ lainnya dipengaruhi oleh Faktor-faktor lain diluar variabel Restitusi PPN.

2. Prosedur pelaksanaan Restitusi PPN pada KPP Pratama Jakarta Penjaringan berdasarkan SOP No KPP50-0004 tentang Tata Cara Penyelesaian Permohonan Pengembalian Kelebihan PPN.

\section{REFERENSI}

Darussalam, Septriadi, D., \& Dhora, K. A. (2018). Konsep Dan Studi Komparasi Pajak Pertambahan Nilai. Jakarta: PT Dimensi Internasional Tax.

Jusmani, \& Qurniawan, R. (2016). Pengaruh Restitusi Pajak Pertambahan Nilai Terhadap Penerimaan Pajak Pertambahan Nilai Pada Kantor Pelayanan Pajak Pratama Palembang Ilir Barat. Media Wahana EKonomika, 13(3), 130-142.

Mardiasmo. (2018). Perpajakan. Yogyakarta: CV Andi Offset.

Pohan, C. A. (2016). Manajemen Perpajakan Strategi Perencanaan Pajak dan Bisnis. Jakarta: PT Gramedia.

Priantara, D. (2015). Perpajakan Indonesia. Jakarta: Mitra wacana Media.

Riftia, D. (2019). Pengaruh Restitusi Kelebihan Pembayaran Pajak Pertambahan Nilai Pada Kantor Pelayanan Pajak Pratama Jakarta Penjaringan. Moneter, 6(1), 63-68.

Sukardji, U. (2014). Pajak Pertambahan Nilai. Jakarta: PT RajaGravindo Persada.

Undang-Undang Nomor 42 Tahun 2009 tentang Perubahan ketiga atas Undang-Undang Nomor 8 Tahun 1983 tentang Pajak Pertambahan Nilai Barang Dan jasa Dan Pajak Penjualan Atas Barang Mewah (Vol. 1994). (2009).

Waluyo. (2010). Akuntansi Pajak (3rd ed.; Ema Sri Suharsi, Ed.). Jakarta.

Wisanggeni, I. (2018). PPN Pada Sektor Industri Khusus. Jakarta: Mitra wacana Media.

\section{PROFIL PENULIS}

Dinar Riftiasari, Lulus S1 Akuntansi Univ Trisakti thn 2008, Lulus S2 Manajemen Univ Trisakti thn 2012, Sebagai Dosen Universitas Bina Sarana Informatika Fakultas Ekonomi Dan Bisnis, jabatan fungsional Asisten Ahli. 